\title{
Effects of Variety and Fungicidal Rate on Cercospora Leaf Spots Disease of Groundnut in the Sudan Savanna
}

\author{
${ }^{1}$ A.S. Muhammad* and ${ }^{2}$ B. S. Bdliya \\ ${ }^{1}$ Crop Science Department, Usmanu Danfodiyo University, Sokoto \\ ${ }^{2}$ Crop Protection Department, University of Maiduguri \\ [Correspondent Author's E-Mail- abkrgwn@yahoo.co.uk]
}

\begin{abstract}
A field study was carried out at the University of Maiduguri Teaching and Research Farm during the 2006, 2007 and 2008 cropping seasons to evaluate the effects of variety and fungicidal rate on Cercospora leaf spot disease of groundnut. The experimental design used was Randomized Complete Block Design (RCBD) with twelve treatment combinations of three varieties of groundnut (Ex-Dakar, RRB and ICGV-86024) and four levels of fungicidal rate (0, 1, 2 and $4 \mathrm{kghaE}$ of fungicide mancozeb) replicated three times. Disease incidence and disease severity were significantly higher in Ex-Dakar and 0 kghaE், thus had lower yields. Higher seed and haulm yield were recorded by RRB, ICGV-86024, as well as 2 and $4 \mathrm{kghaE}$ as a result of lower disease incidence and severity.
\end{abstract}

Keywords: Groundnut; Cercospora leaf spots; Variety; Fungicidal rate; Yield

\section{INTRODUCTION}

In Nigeria leaf spot and rosette virus are the most serious damaging diseases of groundnut (Alabi et al., 1993). Worldwide losses as high as $50 \%$ of the seed yield and even higher for haulms due to Cercospora arachidicola and Cercospora personata have been reported (Salako, 1987; Nyval, 1989; Dewaele and Swanevelder, 2001).

Control of leaf spot diseases in Nigeria has depended on some cultural practices and on multiple applications of fungicides. Effective and long-term control of leaf spot disease can be achieved by applying recommended fungicides at the recommended time intervals. Combination of several control strategies is recommended (Kucharek, 2004). Reduction of initial inoculum is achieved through cultural measures such as crop rotation, removal of volunteer plants, and burial of groundnut residue (Shokes and Culbreath 1997). Spraying with fungicides is required to achieve optimal yields during most years (Bailey et al., 1994). In addition, low to moderate resistance is present in some released cultivars and much effort has been directed at developing cultivars with high levels of leaf spot resistance.

This paper reports the results of an experiment to identify the ideal fungicidal rate and variety of groundnut that will record the lowest incidence and severity of Cercospora leaf spot of groundnut in the Sudan savanna in North-Eastern Nigeria.

\section{MATERIALS AND METHODS}

The study was conducted at the Teaching and Research Farm of the Department of Crop Protection, Faculty of Agriculture, University of

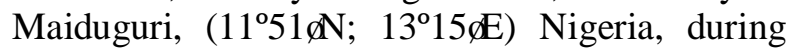
2006, 2007 and 2008 cropping seasons. The soil type of the experimental site was sandy loam and has been classified as typic ustipsamment (Rayar, 1984). The area had been continuously cropped with groundnut for several years resulting in build up of disease inocula. Natural epiphytotics in field were therefore relied upon as the source of inocula in all the seasons. The treatments consisted of factorial combination of four fungicidal rates and three groundnut cultivars, making 12 treatment combinations. The fungicidal rates comprised 0 , 1,2 and $4 \mathrm{kgha} \dot{E}$ of mancozeb which is a wettable powder (WP) whereas the varieties of groundnut included Ex-Dakar, RRB and ICGV 86024. The treatments were laid out in a Randomized Complete Block Design (RCBD) and replicated three times. The layout consisted of three blocks each comprising twelve sub-plots measuring $5 \times 4$ $\mathrm{m}^{2}$ (i.e. $20 \mathrm{~m}^{2}$ ) replicated three times giving a total of 36 plots. A space of one metre $(1 \mathrm{~m})$ was left between the blocks and half-metre $(0.5 \mathrm{~m})$ was left between plots. The total area of experimental plot was $50 \times 13 \cdot \mathrm{m}^{2}\left(1075 \mathrm{~m}^{2}\right)$. The land was ploughed 


\section{Nigerian Journal of Basic and Applied Science (2011), 19 (1): 135-141}

mechanically by tractor followed by leveling with hoe before laying out of plots. The seeds were dressed with seed dressing chemical, Aldrex - T before sowing. Sowing was done manually by hoe using dibbling method. Two seeds per hole were sown. The fertilizer applied was NPK (15:15:15) at the rate of $360 \mathrm{kghaE}$ at sowing. Weeding was done manually by hoe and hand pulling at three weeks and six weeks after sowing. Fungicide application started 4 weeks after sowing and was applied fortnightly using knapsack sprayer according to the treatments. Ten plants were selected randomly in each plot for data collection. Parameters taken were disease incidence, severity, number of pods per stand, seed and haulm yield. Data on disease incidence was taken at 65 days after sowing and at harvest. The number of stands showing symptoms of the diseases in each plot was counted and the percentage of disease incidence was computed. Disease severity assessment was carried out using a scale of 1 to 9 (Subrahmanyam et al., 1995). Ten plants were selected at random which were observed and scored. Based on the extent of disease on each, a scale number was assigned. The data collected were subjected to analysis of variance (ANOVA) based on randomized complete block design and the difference between means was determined using least significant difference (L.S.D) as described by Gomez and Gomez (1984).

\section{RESULTS AND DISCUSSION}

Disease Incidence and Severity: Only in 2007 variety significantly $(\mathrm{P}<0.05)$ influenced disease incidence at 65 days after sowing. Ex-Dakar recorded disease incidence that was significantly $(\mathrm{P}<0.05)$ higher than that recorded by $\mathrm{RRB}$ and ICGV-86024. The two varieties had statistically similar disease incidences (Table 1). With the exception of 2007, there was significant $(\mathrm{P}<0.05)$ difference in disease severity at 65 days after sowing among the three varieties in all the years and their combined analysis. In 2006 and combined analysis, Ex-Dakar had disease severity that was significantly $(\mathrm{P}<0.05)$ higher than that of the remaining two varieties, while in 2008, the disease severity recorded by Ex-Dakar and RRB was statistically similar and that of RRB and ICGV-86024 was also similar. This could be due to difference in host resistance to the disease. Waliyar et al. (1995) as well as Bailey (2002) reported that commercial cultivars vary in their susceptibility to early leaf spots (ELS) and late leaf spots (LLS). Variation and reactions of groundnuts to Cercospora leaf spot disease were also reported by Knauft and Gorbet (1990). Izge et al. (2007) also reported a lot of variability existing among the groundnut varieties evaluated in all characters.

Fungicidal rate was found to significantly $(\mathrm{P}<0.05)$ affect disease incidence at 65 days after sowing in all the years and their combined analysis (Table 1). Result revealed that the untreated check consistently recorded the highest disease incidence, while $4 \mathrm{kghaE}$ on the other hand recorded the lowest, in all the trials and their combined analysis. In 2006, the untreated check and $1 \mathrm{kghaE}$ treatment recorded similar disease incidences, while $1 \mathrm{kgha} \dot{E}$ and $2 \mathrm{kghaE}$ recorded similar disease incidences. Furthermore, the disease incidences recorded by $2 \mathrm{kghaE}$ and 4 kghaE் were also statistically similar. In 2007, 2008 and combined analysis, the trend of disease incidence as affected by application of mancozeb was observed to be similar. Application of 1 kghaE resulted in significant reduction in disease incidence. Increasing the application rate to 2 kghaE caused further significant reduction of the disease incidence. Further doubling of the application rate to $4 \mathrm{kghaE}$ caused further significant $(\mathrm{P}<0.05)$ reduction of the disease incidence except in 2008. The disease incidence was reduced by $42.25 \%, 32.58 \%$ and $17.84 \%$ as the result of respectively spraying mancozeb at the above application rates. The use of fungicide mancozeb (Dithane M54) for the control of plant diseases has been documented (Thapar et al., 1995; Elad et al., 1996) specifically for the control of Cercospora leaf spot in Nigeria (RMRDC, 2004). Fontem and Aighewi (1990) reported that in a trial to test the efficacy of fungicide on late blight of potato in the west province of Cameroon, fungicide sprays significantly reduced epidemic rates and areas under disease progress curves. Vawdrey et al. (2004) reported that disease assessment conducted 2 weeks before harvest showed that mancozeb applied at the rate of $100 \mathrm{~g}$ a.i. haE was less effective than higher rates of 1760,2000 , or $2500 \mathrm{~g}$ a.i.haĖ in controlling yellow Sigatoka disease of banana. On the other hand, Bergquist (1974) reported that there was no 
difference due to different rates of mancozeb applied to control Phytophthora leaf blight of Taro, in the lower rainfall location, but in the wetter location, $4.48 \mathrm{kghaE}$ rate gave better control than the $1.12 \mathrm{kghaE}$ rate. James et al. (2005) also reported that, in the field, chlorothalonil and mancozeb were the most efficacious of the fungicides tested in controlling anthracnose on three cultivars of Euonymus fortunei.

The severity of Cercospora leaf spots also varied among the three groundnut varieties at 65 days after sowing. Disease severity was significantly higher in variety Ex-Dakar than the other varieties, probably due its inherent susceptibility to attack by the pathogens than the other varieties. This result agrees with Izge et al. (2007) who in a study to determine the level of variability of groundnut to Cercospora leaf spot concluded that, the study found a lot of variability existing among the groundnut varieties evaluated in all characters, and that the varieties ICGV-SM-93531, ICGV-IS96802, ICGV-IS-96827 and ICGV-IS-96808 have been found to be tolerant to Cercospora leaf spot disease based on their level of incidence and their respective kernel yield. Bdliya and Muhammad, (2006) also reported that severity of Cercospora leaf spot varied among the three groundnut varieties he studied and the disease severity was significantly higher in Ex-Dakar compared to RMP 12 and Damboa local. Other authors have also reported variation in severity of Cercospora leaf spots on different groundnut varieties (Hemingway, 1957; Subrahmanyam et al., 1983).

The severity of Cercospora leaf spots varied among the fungicidal rates at 65 days after sowing. The lowest severity was recorded by 2 and $4 \mathrm{kghaE}$ rates, while the highest was recorded by the untreated check. This difference in disease severity among the rates of mancozeb application could be attributed to the difference in intrinsic toxicity of the three rates which is determined by the amount of active ingredient of the fungicide applied per unit area. Patel and Patel (1980) fond that chlorothalonil and mancozeb provided satisfactory control of dowry mildew on muskmelon.
Fungicidal rates 1 kgha $\dot{E}, 2$ kghaE and 4 kghaE reduced the severity of Cercospora leaf spots at 65 days after sowing, by $16.84 \%, 31.02 \%$, $32.83 \%$ respectively. The use of fungicide mancozeb (Dithane M54) for the control of plant diseases has been documented (Thapar et al., 1995; Elad et al., 1996) and specifically for the control of Cercospora leaf spot in Nigeria (RMRDC, 2004). There is dearth of literature on the effects of fungicide rate on plant diseases in Nigeria. Nevertheless, Vawdrey et al. (2004) reported that mancozeb applied at the rate of $1 \mathrm{~kg}$ a.i. haE was less effective than higher rates of $1.76,2$ or $2.5 \mathrm{~kg}$ a.i. haE in controlling yellow Sigatoka disease of Banana. On the other hand, Bergquist (1974) reported that there was no difference due to different rates of mancozeb applied to control Phytophthora leaf blight of Taro in the lower rainfall location, but in the wetter location, $4.48 \mathrm{kghaE}$ rate gave better control than $1.12 \mathrm{kghaE}$ rate. These earlier reports corroborate the results of this study.

Number of pods per stand: There was significant difference in number of pods per stand among the groundnut varieties only in 2006. ExDakar recorded significantly the lowest number of pods compared to RRB and ICGV-86024 who had statistically similar number of pods per stand. Generally the lowest number of pods per stand was obtained in 2007 when compared to 2006 and 2008 (Table 2). This could be attributed to the disease tolerance of the variety Ex-Dakar, since the disease severity was more on the variety. This result confirmed the earlier report by Bdliya and Muhammad (2006), who reported that Ex-Dakar is a high-yielding cultivar which requires less rainfall and is more tolerant to the Cercospora leaf spot than RMP 12 and Kano 38. The reason for the three varieties having similar pod yield could be due to the fact that all of them are improved varieties developed to suit the agroecological zone where the study was conducted.

The mean number of pods per stand was significantly higher in groundnut sprayed with mancozeb at the rate of 4 and $2 \mathrm{kghaE}$ than those sprayed at the rate of $1 \mathrm{kghaE}$. The number was generally lower in the untreated control. This could be due the lower disease incidence and severity recorded as a result of application of 
mancozeb compared to the untreated control. The application of mancozeb resulted in pod yield increase from $10.12 \%-29.07 \%, 22.22 \%-63.51 \%$ and $5.33 \%-34.02 \%$ in 2006, 2007 and 2008 rainy season respectively. These results agree with the findings of Naab et al. (2005) who reported that application of foliar sprays of fungicide in Ghana was effective in controlling Cercospora leaf spot and improved groundnut biomass and pod yield by $39 \%$ and $75 \%$ respectively when averaged across cultivars and years. In Nigeria, Salako (1985) investigated the application of a range of fungicides for disease control in groundnuts and reported a yield increase of 132 ï $286 \%$ over unsprayed control plots depending on the fungicide used. In a similar study, Subrahmanyam et al. (1984) observed significant increase in pod yield in all cultivars than in unsprayed plots.

Table 1: Effects of variety and fungicidal rate on incidence and severity of cercospora leaf spots of groundnut during 2006, 2007, 2008 and combined analysis at Maiduguri.

\begin{tabular}{|c|c|c|c|c|c|c|c|c|}
\hline \multirow[b]{2}{*}{ Treatment } & \multicolumn{3}{|c|}{$\begin{array}{c}\text { Incidence of Cercospora }(\%) \\
\text { at } 65 \text { DAS }\end{array}$} & \multirow[b]{2}{*}{ Combined } & \multicolumn{4}{|c|}{$\begin{array}{c}\text { Severity of Cercospora }(\%) \\
\text { at } 65 \text { DAS }\end{array}$} \\
\hline & 2006 & $\begin{array}{l}65 \text { DAS } \\
2007\end{array}$ & 2008 & & 2006 & $\begin{array}{r}\text { at } 6 \\
2007\end{array}$ & $\begin{array}{l}\text { DAS } \\
2008\end{array}$ & Combined \\
\hline \multicolumn{9}{|l|}{ Variety (V) } \\
\hline Ex-Dakar & 45.70 & $57.80 \mathrm{a}$ & 50.71 & 49.43 & $43.13 \mathrm{a}$ & 39.89 & $41.66 \mathrm{a}$ & $41.57 \mathrm{a}$ \\
\hline RRB & 41.92 & $52.40 \mathrm{~b}$ & 48.67 & 48.92 & $26.35 b$ & 37.36 & $38.08 \mathrm{ab}$ & $38.03 b$ \\
\hline ICGV86024 & 39.78 & $52.51 \mathrm{~b}$ & 46.21 & 46.88 & $28.70 \mathrm{~b}$ & 34.54 & $35.45 b$ & $32.90 \mathrm{~b}$ \\
\hline $\mathrm{SE} \pm$ & 3.184 & 0.719 & 2.205 & 0.478 & 1.308 & 1.290 & 1.631 & 1.461 \\
\hline Significance level & Ns & $* *$ & Ns & Ns & $* *$ & Ns & $*$ & $* *$ \\
\hline \multicolumn{9}{|l|}{$\begin{array}{l}\text { Fungicidal rate } \\
\text { (F) }\end{array}$} \\
\hline 4 kghaE $^{1}$ & $33.80 \mathrm{c}$ & $36.68 \mathrm{~d}$ & $38.70 \mathrm{c}$ & $36.39 d$ & $27.03 \mathrm{c}$ & $32.20 \mathrm{c}$ & $31.95 \mathrm{c}$ & $30.40 \mathrm{c}$ \\
\hline 2 kghaÉ1 & $41.58 b c$ & $44.62 \mathrm{c}$ & $41.24 \mathrm{c}$ & $42.48 \mathrm{c}$ & $28.93 c$ & $31.15 \mathrm{c}$ & $33.58 \mathrm{c}$ & $31.22 \mathrm{c}$ \\
\hline 1 kghaÉ1 & $44.24 \mathrm{ab}$ & $60.35 b$ & $50.71 b$ & $51.77 \mathrm{~b}$ & $34.87 \mathrm{~b}$ & $38.55 b$ & $39.53 b$ & $37.64 b$ \\
\hline 0 kghaĖ & $50.25 \mathrm{a}$ & $75.29 \mathrm{a}$ & $63.47 \mathrm{a}$ & $63.01 \mathrm{a}$ & $40.09 a$ & $47.15 \mathrm{a}$ & $48.52 \mathrm{a}$ & $45.26 \mathrm{a}$ \\
\hline $\mathrm{SE} \pm$ & 2.623 & 1.109 & 1.866 & 0.816 & 1.206 & 1.105 & 1.434 & 1.2480 \\
\hline Significance level & $* *$ & $* *$ & $* *$ & $* *$ & $* *$ & $* *$ & $* *$ & $* *$ \\
\hline \multicolumn{9}{|l|}{ Interaction } \\
\hline $\mathrm{V} \times \mathrm{F}$ & Ns & Ns & Ns & Ns & Ns & Ns & Ns & Ns \\
\hline
\end{tabular}

Within a treatment group, means in a column followed by the same letter(s) are not significantly different at $5 \%$ probability according to DMRT.

Seed Yield: Variety of groundnut did not significantly affect seed yield except in 2006. The variety ICGV-86024 had significantly the highest seed yield, followed by RRB, while the lowest was recorded by Ex-Dakar (Table 2). The results also revealed that seed yield was lowest in 2007 when compared with 2006 and 2008. Furthermore, Ex-Dakar yielded higher in 2008, while RRB and ICGV-86024 yielded more in 2006. This might be as a result of moderate resistance to Cercospora leaf spot by RRB and ICGV-86024 varieties in the subsequent years after the first trial in 2006 as well as the disease tolerance of Ex-Dakar variety. Disease tolerance of Ex-Dakar has been reported by Bdliya and Muhammad (2006) as well as RMRDC (2004).

Fungicidal rate also produced significant $(\mathrm{P}<0.05)$ effect on seed yield in all the years and combined analysis. A similar trend of seed yield was observed in 2006 and combined analysis. The results showed that the unsprayed check $(0$ kghaE) significantly and consistently had the lowest seed yield in all the years and combined. The application of mancozeb at the rate of 1 kghaE caused a significant increase in seed yield except in 2007. 
Muhammad and Bidliya: Effects of Variety and Fungicidal Rate on Cercospora Leaf Spots Disease..

Table 2: Effects of variety and fungicidal rate on number of pods per stand, seed and haulm yield of groundnut during the 2006,2007, 2008 and combined analysis at Maiduguri

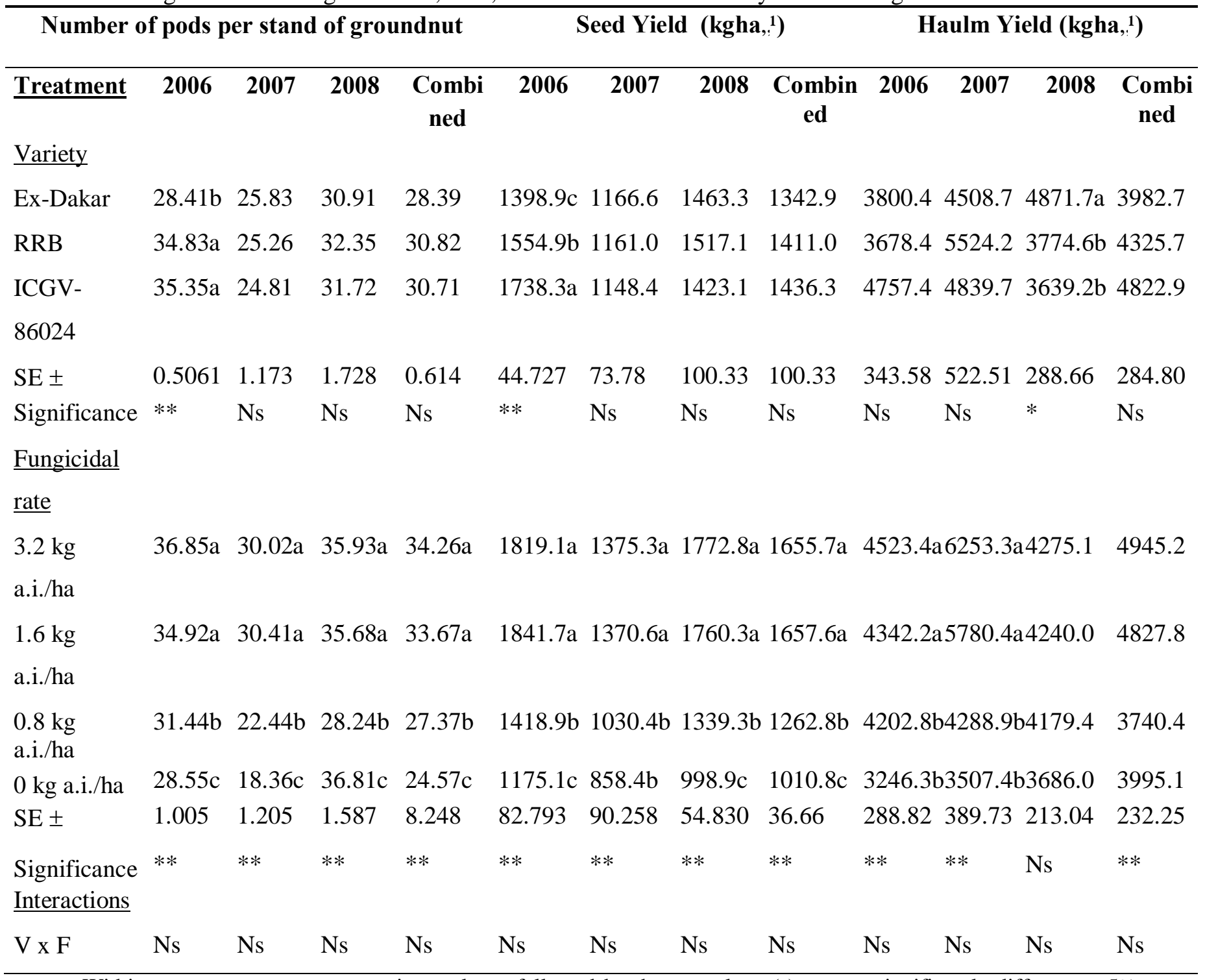

Within a treatment group, means in a column followed by the same letter(s) are not significantly different at 5\% probability according to DMRT.

The seed yield was significantly and successfully increased as a result of increasing the rate of mancozeb application to $2 \mathrm{kghaE}$, in all the years and combined. But further increase of the rate to 4 kghaE did not result in significant seed yield increase in all the years and combined analysis. This could be attributed to the efficacy of mancozeb in reducing the incidence and severity of Cercospora leaf spot disease of groundnut. Efficacy of fungicides on Cercospora leaf spot of groundnut has been reported (Salako, 1985; Naab et al., 2005). Specifically, mancozeb (Dithane
M54) has been reported to provide satisfactory control of Cercospora leaf spot disease of groundnut in northern Nigeria (RMRDC, 2004). Other workers reported its efficacy on other fungal diseases of crops (Grove, 1980; Patel and Patel, 1980).

\section{Haulm Yield}

Variety of groundnut did not significantly $(\mathrm{P}<0.05)$ affect haulm yield except in 2008. ExDakar yielded significantly $(\mathrm{P}<0.05)$ higher haulm than RRB and ICGV-86024. The haulm yields of 
the two varieties were statistically similar (Table 2). Fungicidal rate also produced significant effect on haulm yield of groundnut in 2006, 2007 and combined analysis, 2008 exclusive. In the two years and combined, $0 \mathrm{kghaE}$ and $1 \mathrm{kghaE}$ had statistically similar haulm yield. The yield significantly $(\mathrm{P}<0.05)$ increased due to spraying Mancozeb at the recommended rate of $2 \mathrm{kghaE}$. Increasing the rate to $4 \mathrm{kghaE}$ did not significantly $(\mathrm{P}<0.05)$ increase the haulm yield (Table 2). The fungicidal rate caused a higher haulm yield in 2007 than the remaining years. This result could be attributed to disease tolerance of Ex-Dakar in 2008 which has resulted in more vigorous plants in respect of the higher incidence and severity of early leaf spots coupled with the efficacy of mancozeb in reducing the incidence and severity of Cercospora leaf spot disease of groundnut.

\section{CONCLUSION}

Host resistance or tolerance and adequate fungicidal rate are essential for optimum yield in that they play an important role in the reduction of infection by diseases. Consequently, in this study, the effects of variety and fungicidal rate on Cercospora leaf spot disease of groundnut were evaluated. Disease and yield parameters were accordingly assessed and it was discovered that, the varieties used did not differ much in the parameters assessed as indicated in the combined analysis, but generally ICGV-86024 and RRB outperformed Ex-Dakar in all respect. On the other hand, the untreated control recorded higher disease incidence and severity of Cercospora leaf spot disease. Conversely, application of mancozeb at the rates of $2 \mathrm{kghaE}$ and $4 \mathrm{kghaE}$ resulted in lower disease incidence and severity with corresponding higher yields that were statistically similar. Therefore, 2 kghaE of fungicide mancozeb and either RRB or ICGV-86024 appeared to be more promising and hence recommended.

\section{REFERENCES}

Alabi, O., Olorunju, P.E., Misari, S.M., and Boye-Goni, S.R. (1993). Management of groundnut foliar diseases in Samaru, Northern Nigeria In: Summary Proceedings of the Third ICRISAT Regional Groundnut
Meeting for West Africa W.F. Ntare, and J.H. Williams (eds.) 35 ï 36pp.

Bailey, J.E. (2002). Peanut Disease Management. Pages 63-81 in: 2002 Peanut Information. North Carolina Cooperative Extension, Raleigh.

Bailey, J.E., Johnson, G.L. and Toth, Jr. S.J. (1994). Evolution of a weather- based peanut leaf spot advisory in North Carolina. Plant Disease 78:530- 535.

Bdliya, B.S. and Muhammad, A.S. (2006). Effect of inter-cropping millet with groundnut on the control of cercospora leaf spot of groundnut in the Sudan Savanna of northeastern Nigeria. J. Sust. Agric. 29(2): 19-41.

Bergquist, R.R. (1974). Effect of fungicide rate, Spray interval, timing of spray application, and precipitation in relation to control of

Phytophthora Leaf Blight of Taro. Ann. Bot. 38: 213-221.

Dewaele, D. and Swenevelder, C.J. (2001). Groundnut (Arachis hypogaea L.). In: Crop production in Tropical Africa, ed. Raemakers, R. H. Directorate General for International Co-operation (DGTC) Brussels, Belgium. Pp 747-763.

Elad, Y., Malathrakis, N.E. and Dik, A.J. (1996). Biological control of Botryis-incited diseases and powdery mildews in greenhouse crops. Crop Prot. 15: 229-240.

Fontem, D.A. and Aighewi, B.A. (1990). Effect of fungicides on late blight and yield of potato in the west province of Cameroon. International Society for Horticultural Science Acta Horticulturae 380: Symposium on Tropical Root Crops in a Developing Economy. www.actahort.org

Gomez, K.A. and Gomez, A.A. (1984). Statistical Procedures for Agricultural Research. 2nd edition, John Wiley Sons, New York, 680pp.

Grove, M.D. (1980). Downy mildew control on susceptible cantaloupe. Plant Disease, 64: 390-391.

Hemingway, J.S. (1957). The resistance of groundnut to Cercospora leaf spot. Empire Expt. Agric. 25: 60 ї 68.

Izge, A.U., Muhammad, Z.H. and Goni, H. (2007). Level of Variability in Groundnut (Arachis hypogaea L.) to Cercospora Leaf Spot Disease-Implication for Selection. $J$. Sust. Dev. Agric. Environ. 2(2): 
Muhammad and Bidliya: Effects of Variety and Fungicidal Rate on Cercospora Leaf Spots Disease..

James, T.C., Janet, C.C. and Kenneth, E.C. (2005). Effectiveness of selected fungicides applied with or without surfactant in controlling anthracnose on three cultivars of Euonymus fortunei. J. Appl. Horticul. 7(1): 16-19.

Knauft, D.A. and Gorbet, D.W. (1990). Variability in growth characteristics and leaf spot resistance parameters of peanut lines. Crop Sci. 10(1): 169 ï 175.

Kucharek, T. (2004). Florida Plant Disease Management Guide: Control for Diseases of Vegetables Revision No. 16.

Naab, J.B., Tsigbey, F.K., Prasad, P.V.V., Boote, K.J., Bailey, J.E. and Brandenburg, R.L. (2005). Effects of sowing date and fungicide application on yield of early and late maturing peanut cultivars grown under rainfed conditions in Ghana. Crop Prot. 24(4): 325-332.

Nyval, R.F. (1989). A Handbook of Field Crop Disease, Second Edition, pp. 31-321.

Patel, J.G. and Patel, A.J. (1980). Efficacy of systemic and non systemic fungicides on the control of downy mildew of muskmelon. Indian J. Mycol. Plant Pathol. 10: 87.

Rayar. A. J. (1984). Effect of organic manure on soil properties. Unpublished Research of the University of Maiduguri.

RMRDC (2004). Raw Materials Research and Development Council: Report on survey of selected Agricultural Raw Materials in Nigeria. www.rmrdc. Gov.nig/ Survey report 2005/Groundnut

Salako. E.A. (1985). Fungicidal control of groundnut leaf spots and rust by ultra-low volume spray. Trop. Pest Manag. 31: 63 66.

Salako, E.A. (1987). Summary of terminal report on groundnut pathology trials 1980-1986. Legumes and Oilseeds Research Program, Cropping Scheme Meeting 1987. Institute of Agricultural Research, Ahmadu Bello University, Samaru, Zaria, Nigeria.
Shokes, F.M. and Culbreath, A.K. (1997). Early and late leaf spots. Pages 17-20 in: Compendium of Peanut Diseases, Second Edition. N. Kokalis-Burelle, D.M. Porter, R. Rodriguez-Kabana, D.H. Smith, and P. Subrahmanyam, eds. American Phyotpathology Society., St. Paul.

Subrahmanyam, P., Hammons, R.O., Nigam, S.N., McDonald, D., Gibbons, R.W., Fan, M.Y. and Yeh, W.L. (1983). International cooperative screening for resistance of peanut to rust and leaf spot. Plant Disease, 67:1108-111.

Subrahmanyam, P., Williams, J. H., Mc Donald, D. and Gibbons, R. W. (1984). The influence of foliar diseases and their control by selective fungicides on a range of groundnut (Arachis hypogaea L.) genotypes. Ann. Appl. Bio. 104: 467-476.

Subrahmanyam, P., McDonald, D. Utayor F., Reddy, L.J., Nigam, S.N., Gibbon, R.W., Singh, V.R., Pandes, A.K., Reddy, P.M. and Pao P.V. (1995). Resistance to Rust and Late leaf Spot of Groundnut. ICRISAT Information Bulletin. No.47, Patancheru, 502, 324, Andra Pradesh, India. P.24.

Thapar, S., Bhusham, R. and Mathur, R.P. (1995). Degradation of organophosphorus and carbamate pesticides in soils-Hple determination. Tan-fed 9(1): 18-22.

Vawdrey, L.L., Peterson, R.A., DeMarchi L. and Grice, K.E. (2004). Evaluation of mineral oils and plant-derived spray adjuvants, mancozeb formulations and rates of application, for the control of yellow Sigatoka leaf spot (Mycosphaerella musicola) of bananas in far northern

Queensland, Australia. Aust. Plant Pathol. 33(3): 379 ï 384.

Waliyar, F., Shew, B., Sidahmed, B. R. and Beute, M.K. (1995). Effects of host resistance on germination of Cercospora arachidicola on peanut leaf surfaces. Peanut Science. 22: 154-157. 